\title{
Bone Marrow Stem Cell Committed to the Megakaryocytic Lineage
}

National Cancer Institute

\section{Source}

National Cancer Institute. Bone Marrow Stem Cell Committed to the Megakaryocytic

Lineage. NCI Thesaurus. Code C43221.

A primitive undifferentiated cell which can undergo division and can give rise to one of the early megakaryocytes. 